\title{
Processing and preservation qualities of value added products based on Garcinia cambogia [Malabar Tamarind]
}

\author{
Aparna S Gopakumar ${ }^{1}$, Dr. Kavita M S ${ }^{2}$ \\ I'Research Scholar, Department of Home Science, St. Teresa's College/ Mahatma Gandhi University, India) \\ ${ }^{2}$ (Asst. Professor, Department of Home science, Govt. College for Women/Kerala University, India)
}

\begin{abstract}
Garcinia cambogia is a sub tropical fruit found in the Western Ghats of India as well as in SouthEast Asia. Garcinia or Malabar tamarind has greater dietary importance and it is widely utilized in the preparation of refreshing drinks, for curing fishes, in fish curries etc. Garcinia had proven medicinal effects and is used in treating conditions like flatulence, oedema, chronic alcoholism, dysentery, diarrhea, obesity etc. The nutraceutical effects of Garcinia cambogia is due to the presence of an acid known as HCA or (-) - hydroxy citric acid in it. This higher hydroxy citric acid content in Garcinia makes it an effective anti- obesity agent because of its appetite reducing property by inhibiting the enzyme ATP-citrate lyase which helps in the conversion of carbohydrates to glycogen. Even though Garcinia cambogia had a number of nutraceutical effects, its use is under exploited in our country which resulted in the wastage of these fruits during the seasonal glut. Processing techniques like osmotic pressure, controlled $\mathrm{pH}$, dehydration and utilization of fruits in the preparation of fruit beverages were selected for the preparation of value added products using Garcinia cambogia. In the present context, the current study explores the possibilities of applying different traditional processing techniques in producing more varieties of products incorporating Garcinia fruits. Thus it helps in increasing the usage of the fruit by making it available throughout the year. The study also evaluated the shelf life and economic qualities of the prepared products. The study thus helped in succesfully formulating ten recipes incorporating Garcinia. Among the developed products Garcinia preserve prepared by employing preservation technique utilizing osmotic pressure got the highest acceptability among a selected panel. Also Garcinia products developed using osmotic pressure was found to be having the highest shelf life. From the study it can be concluded that the processing of Garcinia using sugar and salt which employed the technique of osmotic pressure preservation proved to develop products having superior quality when compared to other processing techniques.
\end{abstract}

Keywords: Fruits, Garcinia cambogia, Nutraceuticals, Processing, Value added products, Shelf life

\section{INTRODUCTION}

Fruits have been a major food for mankind, from time immemorial and even to primitive man the food was based mainly on fruits and also tubers which were found in the forest ${ }^{[1]}$. India with its diverse, but favorable agro climatic conditions produces a wide range of tropical and temperate fruits and vegetables. India is one of the largest producers of fruits (27 million tones) in the world ${ }^{[2]}$. Some of them are seasonal while others are available throughout the year. Surplus production of perishable fruits and vegetables during the seasonal glut could be converted into durable products in order to avoid wastage. Fruits and vegetables if effectively utilized can carry $20-23$ tonnes higher foreign exchange per unit area than cereals ${ }^{[3]}$. Under exploited fruits are the several less known fruit species which have the potential for commercial exploitation and are yet to be utilized for their potential. Most of the underutilized fruits are considered to possess some medicinal properties. Such produces are termed as 'Nutraceuticals' in the market ${ }^{[4]}$.

Garcinia cambogia (Malabar tamarind), which belongs to the family Clusiaceae or Guttiferae, is an evergreen tree grown in Western Ghats of Kerala and Maharashtra. The fruit rind of Garcinia had nutraceutical properties in treating conditions like flatulence, oedema, chronic alcoholism, dysentery, diarrhea, obesity etc. The nutraceutical effects of fruit rind of Garcinia are due to the presence of Hydroxy Citric Acid (HCA), which makes it an anti obesity agent because of its appetite reducing property by inhibiting the enzyme ATP-citrate lyase which in turn helps in the conversion of carbohydrates to glycogen. Garcinia is described as "Nature's Natural Fat Buster" or "Remarkable Herb" ${ }^{[5]}$. It is commonly used in India as a food as well as medicine. In Indian folk medicine and Ayurveda, Garcinia has been used for ailments such as rheumatism, bowel disorder etc. The dried rind of the fruit and its extracts are used in Indian curry dishes as a condiment.

Drying, an old age method for preserving food is the existing preservation technique for Garcinia. Garcinia produced in excess, can be converted to more durable value added products by applying modern preservation and processing techniques, in order to avoid wastage during seasonal glut. If utilized properly, medicinally and nutritionally valuable Garcinia can be processed into a variety of food products. 
In this context, the present study titled "Processing and preservation qualities of value added products based on Garcinia cambogia [Malabar Tamarind]" was done with an aim to fully exploit the processing capacity of Garcinia and the shelf stability of the products.

\section{Methodology}

The methodology pertaining to the study involved the following steps:

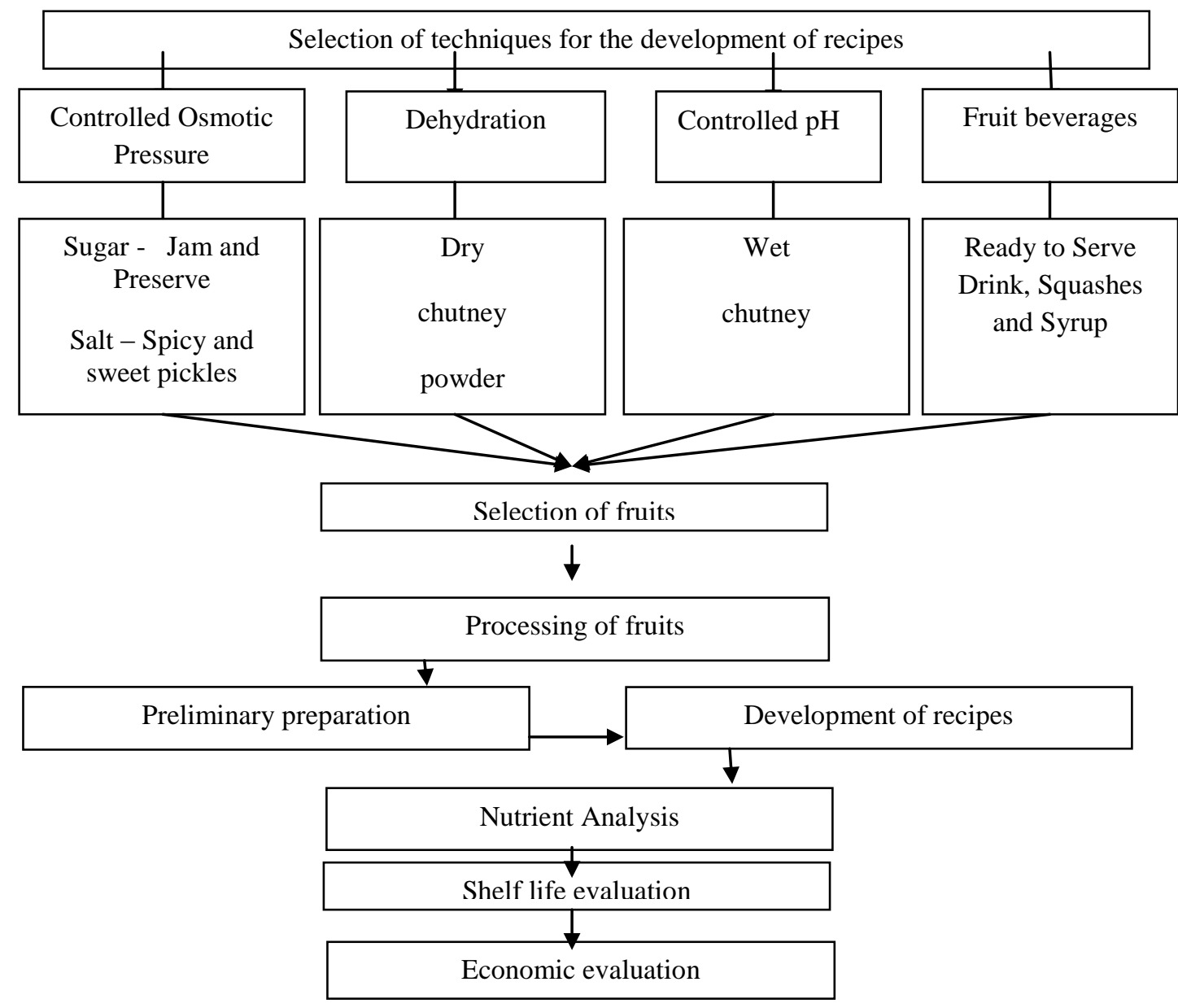

Figure 1 Steps involved in the methodology

\subsection{Selection of processing techniques for the development of recipes}

Based on the principles of preservation and in order to enhance the shelf life properties, techniques of preservation such as use of controlled osmotic pressure, controlled $\mathrm{pH}$, dehydration and preparation of fruit beverages were selected for the preparation of the products using Garcinia cambogia.

\section{2. $\quad$ Selection of recipes}

Out of the twenty recipes planned, ten recipes namely jam, preserve, spicy pickle, sweet pickle, dry chutney powder, wet chutney, Garcinia watermelon ready to serve drink, Garcinia orange squash, Garcinia pineapple squash and Garcinia lime ginger syrup, which were considered more appealing, nutritious and easy to prepare were selected for development. Fig. 1 represents the different steps involved in methodology.

\subsection{Selection of fruits for the study}

Fresh mature fruits of medium ripeness without any post harvest injuries were procured from local farmers. Figure 2 shows the picture of Garcinia fruits. 


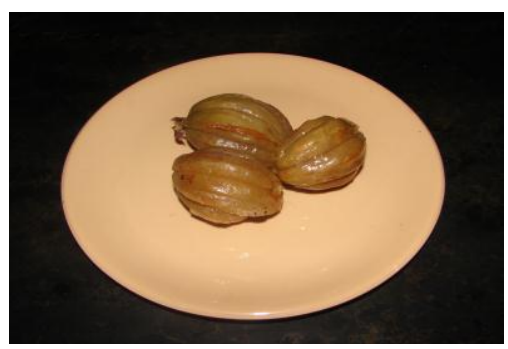

Figure 2 Garcinia cambogia fruits

\subsection{Processing and preservation of Garcinia fruits}

\subsubsection{Preliminary preparation of the fruits for processing}

Raw fruits were cleaned thoroughly with water to remove any adhering dirt and other undesirable substances. They were then cut in to two halves and the seeds along with the seed covering were removed from the fruit. Using a knife, the pulpy seed covering was then separated from the seeds and seeds were discarded while the seed covering was utilized for preparing the products along with the fruit flesh. The fruit halves were then cut in to small cubes.

The fruits were used as such for preparing sweetened sugar based products like jam, preserve, beverages etc. For the preparation of pickles and chutneys, the fruit pieces were mixed with a small amount of salt and kept for fifteen minutes. It was done in order to remove the astringency of raw fruit. Excess salt is removed by washing the fruit pieces with water, after fifteen minutes.

\subsubsection{Processing and preservation of Garcinia using controlled osmotic pressure}

Using the principle of controlled osmotic pressure, products like jam, preserve, pickles etc were prepared with Garcinia.

\subsubsection{Preparation of Garcinia jam and preserve}

Jam and preserve were the two recipes selected for incorporating Garcinia, which employs controlled osmotic pressure using sugar as medium for preservation. For the preparation of both jam and preserve, the fruits of Garcinia were at first washed, then cut into small pieces and deseeded.

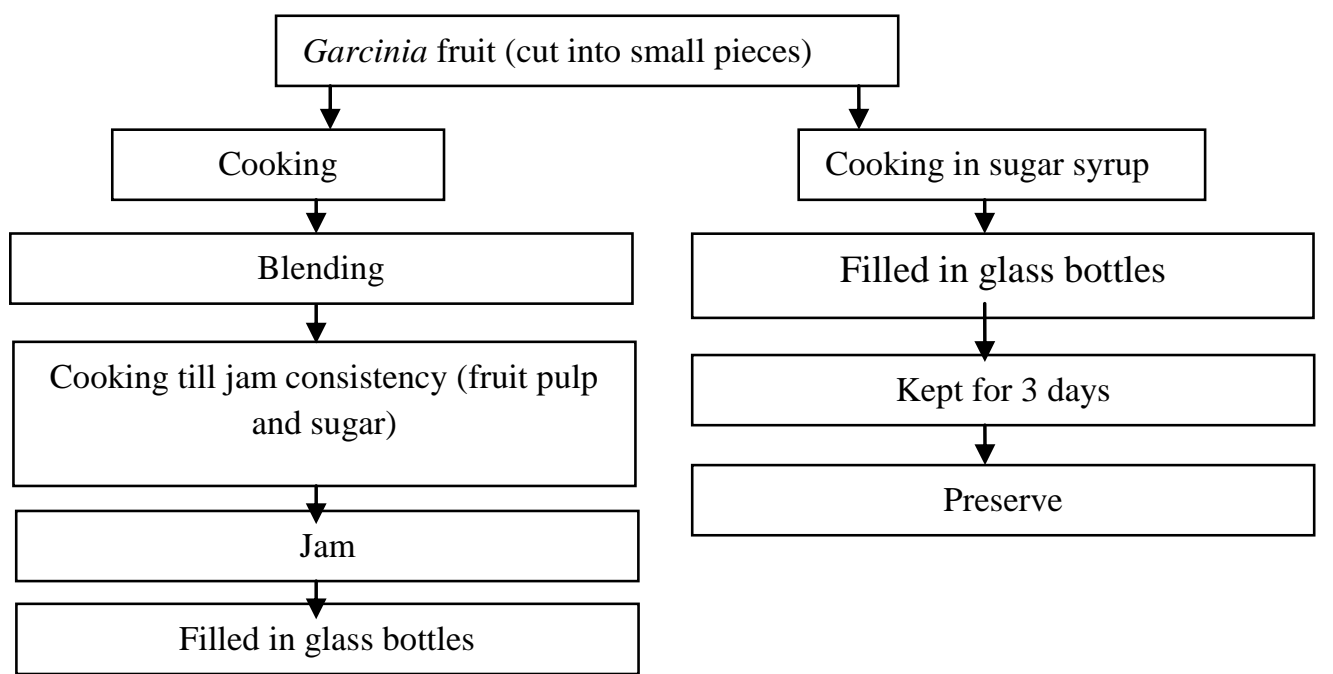

Figure 3 Preparation of Garcinia jam and preserve

\subsubsection{Preparation of spicy and sweet pickles using Garcinia}

Garcinia fruits were processed into spicy and sweet pickles using salt as a medium for preservation. For the preparation of sweet pickle Garcinia was incorporated with good quality dates, to impart sweetness and to add more nutritional value to the product. The steps involved in the preparation of pickles are given in Fig. 4 . 


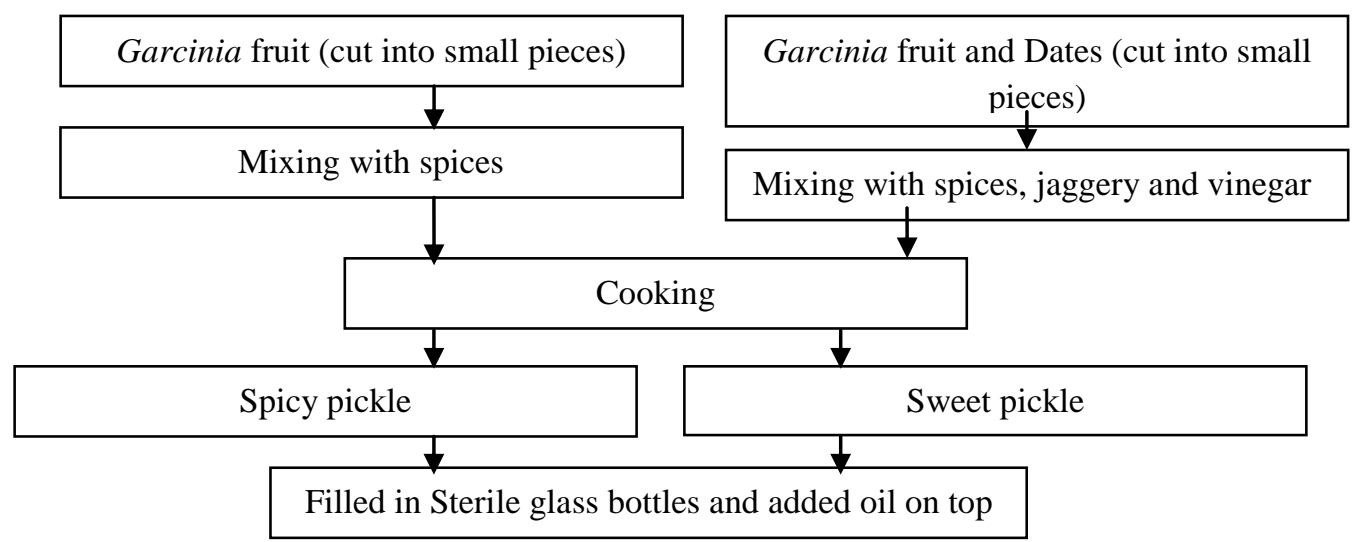

Figure 4 Preparation of spicy and sweet pickles

\subsubsection{Processing and preservation of Garcinia using dehydration and controlled $\mathrm{pH}$}

Garcinia was processed into dry and wet chutney powders by applying the techniques of preservation by dehydration and controlled $\mathrm{pH}$ respectively. The major ingredients for preparing dry chutney powder were Garcinia (30 per cent), coconut (100 per cent), ginger ( 2 per cent), garlic ( 2 per cent) and black gram dhal ( 2 per cent) without the addition of oil. For preparing wet chutney, coconut as well as vinegar was added along with Garcinia. The steps involved in the preparation of Garcinia dry and wet chutney powders are given in Fig.5

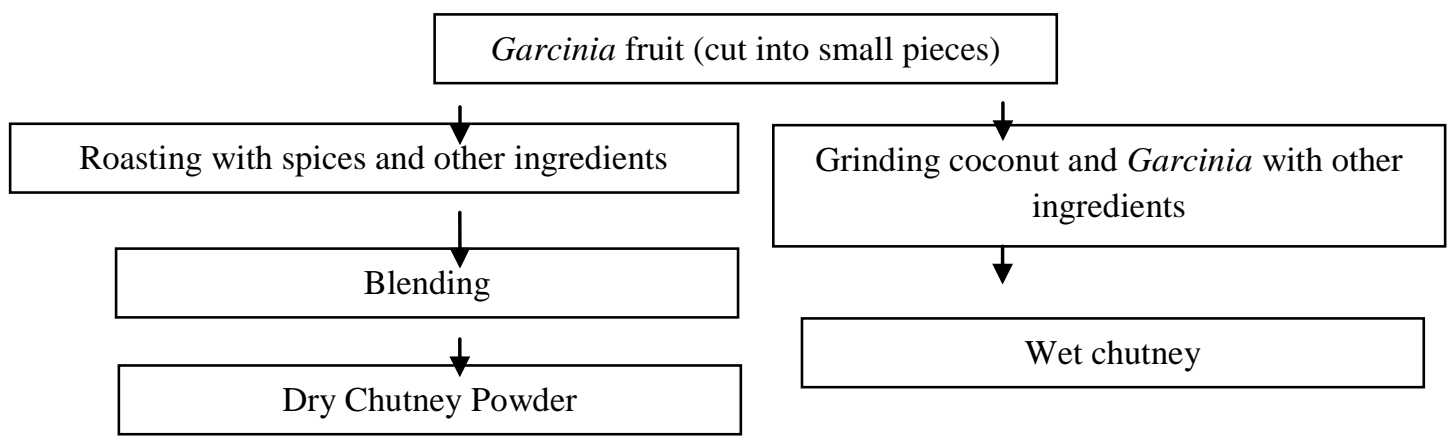

Figure 5 Preparation of Dry Chutney Powder and Wet Chutney

\subsubsection{Preparation of fruit beverages incorporating Garcinia}

Garcinia juice was blended with juices of other fruits to enhance the flavor as well as the nutritive value of the product. A Ready To Serve drink was prepared by using Garcinia juice (100 per cent) and watermelon (100 per cent) in equal amounts, blended in adequate proportions of water and sugar. Two types of squashes were prepared using Garcinia juice (100 per cent) blended with juices of fruits like oranges (50 per cent) and pineapple (50 per cent). A syrup or sharbat, highly popular as "summer drinks" was also prepared by using Garcinia juice, lime juice and ginger.

\subsection{Nutrient analysis of the developed products per serving}

The nutrient content of the developed products per serving was calculated using Nutrient Composition Tables on the basis of their calorie, carbohydrates, proteins, fats, vitamin $\mathrm{C}$ and crude fiber content ${ }^{[6]}$. The percentage contribution by Garcinia cambogia in the total content of each nutrient present in each product were also calculated from the nutrient composition of Garcinia cambogia and the amount of Garcinia used in the preparation of each product.

\subsection{Evaluation of the shelf life qualities of the developed products}

Shelf life is defined as the time during which the food products will remain safe; will be certain to retain their desired sensory, chemical, physical and microbiological characteristics ${ }^{[7]}$. For testing the shelf life of the developed products, the two sets of each prepared product was packed in air tight glass bottles ( $100 \mathrm{~g} / \mathrm{bottle})$. The bottles were then kept at room temperature and at refrigerated storage, for a period of 3 months. During the storage period, the bottles were visually examined for detecting any color change or microbial infestations. At 
the end of the third month, the samples were removed from their bottles for analysis and were visually examined for the growth of colonies of microbes.

\subsection{Economic evaluation of the products}

The products were then evaluated on the basis of the time taken for preparation, yield ratio, preparation loss and cost of production, to find out the most economic product.

\subsubsection{Time analysis}

The time taken for preparing $25 \mathrm{~g}$ of each product was assessed for measuring the easiness with which the products were prepared. It was calculated on the basis of the time taken for preliminary preparations and the time taken for cooking the products.

\subsubsection{Analysis of yield ratio}

Yield ratios of each product were assessed on the basis of the raw weight of the ingredients and the weight of the edible portion after cooking.

$$
\text { Yield Ratio }=\text { Weight of the raw ingredients } / \text { Weight of the edible portion }
$$

\subsubsection{Analysis of preparation loss}

The preparation loss of each product during cooking is calculated from the weight of the purchased raw materials and weight of the edible portion.

$$
\text { Preparation Loss }=\frac{\text { (Purchased ingredients weight }- \text { Edible portion weight })}{\text { Purchased ingredients weight }} \mathrm{g}
$$

\subsubsection{Cost analysis}

The cost for preparing 100g of each product was calculated based on the total cost and weight of the edible portions of the prepared products.

$$
\text { Cost }=\frac{\text { Total cost }}{\text { Weight of the edible portion }} \times 100
$$

\section{Results And Discussion}

The findings of the study can be discussed under the following heads:

\begin{tabular}{|c|c|c|c|c|c|c|c|}
\hline Product name & $\begin{array}{l}\text { Amount g per } \\
\text { serving }\end{array}$ & $\begin{array}{c}\text { Calories } \\
\text { (Kcal) }\end{array}$ & $\begin{array}{c}\text { Carbohydrate } \\
\text { (g) }\end{array}$ & $\begin{array}{l}\text { Protein } \\
\text { (g) }\end{array}$ & $\begin{array}{c}\text { Fat } \\
\text { (g) }\end{array}$ & $\begin{array}{c}\text { Vitamin } \\
\mathbf{C} \\
(\mathbf{m g})\end{array}$ & $\begin{array}{c}\text { Fiber } \\
(\mathrm{g})\end{array}$ \\
\hline Jam & 5 & $\begin{array}{l}25.26 \\
(1.06) \\
\end{array}$ & $\begin{array}{c}5.09 \\
(0.11) \\
\end{array}$ & $\begin{array}{c}0.10 \\
(4.75)\end{array}$ & $\begin{array}{c}\mathbf{0 . 5 0} \\
(5.00) \\
\end{array}$ & $\begin{array}{c}1.50 \\
(5.00)\end{array}$ & $\begin{array}{r}0.71 \\
(5.00) \\
\end{array}$ \\
\hline Preserve & 5 & $\begin{array}{l}15.31 \\
(1.75)\end{array}$ & $\begin{array}{c}2.60 \\
(0.23)\end{array}$ & $\begin{array}{c}0.09 \\
(4.87)\end{array}$ & $\begin{array}{c}0.50 \\
(5.00)\end{array}$ & $\begin{array}{c}1.50 \\
(5.00)\end{array}$ & $\begin{array}{c}0.71 \\
(5.00) \\
\end{array}$ \\
\hline Spicy Pickle & 3 & $\begin{array}{l}12.90 \\
(1.24)\end{array}$ & $\begin{array}{c}0.15 \\
(1.38)\end{array}$ & $\begin{array}{c}0.15 \\
(1.88)\end{array}$ & $\begin{array}{c}0.75 \\
(1.20)\end{array}$ & $\begin{array}{l}0.099 \\
(2.72)\end{array}$ & $\begin{array}{c}0.48 \\
(2.64)\end{array}$ \\
\hline Sweet pickle & 3 & $\begin{array}{l}13.06 \\
(0.73)\end{array}$ & $\begin{array}{c}1.43 \\
(0.15)\end{array}$ & $\begin{array}{c}0.12 \\
(\mathbf{1 . 3 3})\end{array}$ & $\begin{array}{c}0.75 \\
(1.18)\end{array}$ & $\begin{array}{c}1.03 \\
(2.60)\end{array}$ & $\begin{array}{c}0.54 \\
(2.36)\end{array}$ \\
\hline $\begin{array}{ll}\text { Dry } & \text { chutney } \\
\text { powder } & \\
\end{array}$ & 6 & $\begin{array}{l}29.25 \\
(0.39) \\
\end{array}$ & $\begin{array}{c}0.94 \\
(0.27) \\
\end{array}$ & $\begin{array}{c}0.34 \\
(0.60)\end{array}$ & $\begin{array}{c}2.67 \\
(0.40)\end{array}$ & $\begin{array}{c}\mathbf{0 . 6 2} \\
(\mathbf{5 . 2 0})\end{array}$ & $\begin{array}{c}0.47 \\
(3.22) \\
\end{array}$ \\
\hline Wet chutney & 8 & $\begin{array}{l}38.76 \\
(0.53)\end{array}$ & $\begin{array}{c}0.92 \\
(0.37)\end{array}$ & $\begin{array}{c}0.42 \\
(0.87)\end{array}$ & $\begin{array}{c}2.67 \\
(0.40)\end{array}$ & $\begin{array}{c}1.33 \\
(4.32)\end{array}$ & $\begin{array}{r}0.64 \\
(4.20) \\
\end{array}$ \\
\hline
\end{tabular}

\subsection{Nutrient analysis of the prepared products per serving}

Table 1 A Nutrient composition of the developed products per serving *

*Numbers in brackets indicates percentage of nutrient contributed by Garcinia cambogia 
Table 1 B Nutrient composition of the developed products per serving*

\begin{tabular}{|c|c|c|c|c|c|c|c|}
\hline Product name & $\begin{array}{l}\text { Amount g per } \\
\text { serving }\end{array}$ & $\begin{array}{l}\text { Calories } \\
\text { (Kcal) }\end{array}$ & $\begin{array}{c}\text { Carbohydrate } \\
\text { (g) }\end{array}$ & $\begin{array}{l}\text { Protein } \\
\text { (g) }\end{array}$ & $\begin{array}{l}\text { Fat } \\
(\mathrm{g})\end{array}$ & $\begin{array}{c}\text { Vitamin } \\
\mathrm{C} \\
(\mathrm{mg})\end{array}$ & $\begin{array}{l}\text { Fiber } \\
\text { (g) }\end{array}$ \\
\hline $\begin{array}{l}\text { Garcinia water } \\
\text { melon drink }\end{array}$ & 50 & $\begin{array}{c}559.04 \\
(4.70)\end{array}$ & $\begin{array}{l}127.10 \\
(0.47)\end{array}$ & $\begin{array}{c}1.18 \\
(40.50)\end{array}$ & $\begin{array}{c}5.10 \\
(49.01)\end{array}$ & $\begin{array}{c}15.50 \\
(48.35)\end{array}$ & $\begin{array}{c}7.24 \\
(49.30)\end{array}$ \\
\hline $\begin{array}{l}\text { Garcinia } \\
\text { Orange Squash }\end{array}$ & 50 & $\begin{array}{r}555.49 \\
(4.82)\end{array}$ & $\begin{array}{c}125.92 \\
(0.47)\end{array}$ & $\begin{array}{c}1.13 \\
(42.25)\end{array}$ & $\begin{array}{c}5.25 \\
(47.61)\end{array}$ & $\begin{array}{c}31.00 \\
(24.15)\end{array}$ & $\begin{array}{c}0.71 \\
(5.00)\end{array}$ \\
\hline $\begin{array}{l}\text { Garcinia } \\
\text { pineapple } \\
\text { squash }\end{array}$ & 50 & $\begin{array}{c}562.56 \\
(4.76)\end{array}$ & $\begin{array}{c}128.15 \\
(0.46)\end{array}$ & $\begin{array}{c}1.18 \\
(40.50)\end{array}$ & $\begin{array}{c}5.02 \\
(49.75)\end{array}$ & $\begin{array}{c}24.75 \\
(30.30)\end{array}$ & $\begin{array}{c}7.26 \\
(40.10)\end{array}$ \\
\hline $\begin{array}{l}\text { Garcinia lime } \\
\text { ginger syrup }\end{array}$ & 50 & $\begin{array}{l}665.86 \\
(4.02) \\
\end{array}$ & $\begin{array}{l}\mathbf{1 5 3 . 1 4} \\
(0.39) \\
\end{array}$ & $\begin{array}{c}1.50 \\
(31.83) \\
\end{array}$ & $\begin{array}{c}5.25 \\
(47.60) \\
\end{array}$ & $\begin{array}{c}0.80 \\
(24.35) \\
\end{array}$ & $\begin{array}{c}7.48 \\
(47.65) \\
\end{array}$ \\
\hline
\end{tabular}

*Numbers in brackets indicate percentage of nutrient contributed by Garcinia cambogia

The amount of nutrients supplied by each nutrient per serving of the products given in the Table $1 \mathrm{~A}$ and Table 1B indicated the amount of nutrient supplied per serving of the product. The tables revealed that most of the nutrients were found to be higher for Garcinia lime ginger syrup with a calorie content of $665.86 \mathrm{Kcal}$, carbohydrate content of $153.14 \mathrm{~g}$, protein $(1.508 \mathrm{~g})$, fat $(5.25 \mathrm{~g})$, vitamin C $(30.80 \mathrm{mg})$ and crude fiber content of about $7.48 \mathrm{~g}$. Thus it can be considered as the most nutrient rich product when compared to other developed products. All the nutrients supplied per serving, by the developed products were sufficient to maintain a safety level in adequate proportions without exceeding the normal intake levels of each nutrient per serving.

\subsection{Shelf life qualities of the products}

The shelf life qualities of the developed products were assessed for a period of 3 months. Two sets of all the products (each containing 100g) were kept for a period of 3 months under room temperature and refrigerator storage respectively. Both the sets of each product were examined visually for microbial infestation and noted down the period in which first infiltration was seen. That period was taken as the shelf life of the product under normal room temperature and refrigeration temperature.

Table 2 Shelf life qualities of the developed products

\begin{tabular}{|l|l|l|l|}
\hline \multicolumn{1}{|c|}{ Product } & $\begin{array}{c}\text { Storage } \\
\text { capacity/bottle } \\
\text { (ml) }\end{array}$ & \multicolumn{2}{c|}{ Shelf life } \\
\cline { 3 - 4 } & & \multicolumn{1}{c|}{$\begin{array}{c}\text { Room } \\
\text { Temperature }\end{array}$} & \multicolumn{1}{c|}{ Refrigerator } \\
\hline Jam & 100 & 3 months & 3 months \\
\hline Preserve & 100 & 2 months & 3 months \\
\hline Spicy Pickle & 100 & 2 months & 3 months \\
\hline Sweet pickle & 100 & 2 months & 3 months \\
\hline Dry chutney powder & 100 & 1 week & 2 weeks \\
\hline Wet chutney & 100 & 1 day & 11 day \\
\hline $\begin{array}{l}\text { Garcinia } \text { water melon } \\
\text { drink }\end{array}$ & 100 & 18 days & 1 months \\
\hline $\begin{array}{l}\text { Garcinia } \text { orange } \\
\text { squash }\end{array}$ & 100 & 3 months & 3 months \\
\hline $\begin{array}{l}\text { Garcinia } \text { pineapple } \\
\text { squash }\end{array}$ & 100 & 3 months & 3 months \\
\hline $\begin{array}{l}\text { Garcinia } \text { lime ginger } \\
\text { syrup }\end{array}$ & 100 & 3 months & 3 months \\
\hline
\end{tabular}

Among the products stored at room temperature, Garcinia incorporated fruit beverages namely, Garcinia orange squash, Garcinia pineapple squash and Garcinia lime ginger syrup completed the period of shelf life evaluation without showing any visible deterioration, whereas products like wet and dry chutneys got the least shelf life of 1 day and 1 week respectively. Among the beverages, Garcinia watermelon Ready to Serve drink has got the lowest shelf life of 18 days at room temperature. Products like preserve, spicy and sweet pickles got shelf lives of 2 months each. Garcinia jam has got a shelf life of about 3 months at room temperature.

Under refrigeration storage, all the products preserved using controlled osmotic pressure namely, Garcinia jam, preserve, spicy pickle and sweet pickle completed shelf life of 3 months, without any unacceptable changes. All the beverages incorporated with Garcinia, got 3 months shelf life except Garcinia watermelon RTS drink which got a shelf life of 1 month under refrigeration. Dry chutney powder and wet chutney powder, when stored in refrigerator, scored least shelf lives of 2 weeks and $1 \frac{1 / 2}{2}$ days respectively. 
Sugar, salt and oil were the major preservatives used in the preparation of the products. Thus the products like jam ( $21 / 2$ months), preserve ( 2 months), spicy pickle ( 2 months) and sweet pickle ( 2 months) got the highest shelf life. All these products were prepared on the basis of preservation by osmotic pressure. All the fruit beverages got a maximum shelf life of about 3 months both at room temperature and refrigerator storage, except in the case of Ready To Serve which lasted for about 18 days. Ready To Serve beverages, since they are ready to serve has got low shelf life when compared to other beverages ${ }^{[8]}$.

Wet chutneys prepared using the principle of controlled $\mathrm{pH}$ got the least shelf life due to their high moisture content of the ingredients like coconut and Garcinia. This increased moisture content favored the growth of microbes in the product ${ }^{[9]}$. Since wet chutney was a product with a moisture content of about $93 \mathrm{~g}$, this product had the least shelf life. Dry chutney powder prepared using dehydration techniques resisted microbial attack for about as the ingredients like coconut and Garcinia were dehydrated well.

\subsection{Economic evaluation of the developed products}

The products developed from Garcinia cambogia were economically evaluated on the basis of time taken for their preparation, the yield ratio, preparation loss and cost analysis.

\subsubsection{Time analysis}

\begin{tabular}{|l|c|c|c|c|}
\hline \multirow{2}{*}{ Product Name } & Amount (g) & \multicolumn{3}{c|}{ Time taken } \\
\cline { 3 - 5 } & & $\begin{array}{c}\text { Preliminary } \\
\text { preparation } \\
\text { (minutes) }\end{array}$ & $\begin{array}{c}\text { Cooking } \\
\text { (minutes) }\end{array}$ & $\begin{array}{c}\text { Total time taken } \\
\text { (minutes) }\end{array}$ \\
\hline Jam & & 5 & 10 & 15 \\
\hline Preserve & 25 & 5 & 15 & 20 \\
\hline Spicy Pickle & 25 & 15 & 10 & 25 \\
\hline Sweet pickle & 25 & 15 & 15 & 30 \\
\hline Dry chutney powder & 25 & 10 & 15 & 25 \\
\hline Wet chutney powder & 25 & 7 & 0 & 7 \\
\hline Garcinia - watermelon drink & 25 & 15 & 10 & 25 \\
\hline Garcinia - orange squash & 25 & 20 & 10 & 30 \\
\hline Garcinia - pineapple squash & 25 & 25 & 10 & 35 \\
\hline Garcinia - lime- ginger syrup & 25 & 30 & 20 & 50 \\
\hline
\end{tabular}

The data depicted in the Table 3 revealed that the time taken for cooking Garcinia lime ginger syrup was the highest because of longer period of time taken for the preliminary preparation. Time taken in making or extracting juices from Garcinia and lemon was the highest which took about 30 minutes to complete and also the cooking time was longer ( 20 minutes).Least time for preparation was taken for wet chutney, which took a preparation time of 7 minutes. Since all the ingredients were blended raw in a mixer to form a paste and no cooking was done, this product took the least time for preparation.

\subsubsection{Yield Ratio of the developed products}

Table 4 Yield Ratio

\begin{tabular}{|l|c|c|c|}
\hline \multicolumn{1}{|c|}{ Products } & $\begin{array}{c}\text { Raw weight } \\
\text { (g) }\end{array}$ & $\begin{array}{c}\text { Cooked weight } \\
\text { (g) }\end{array}$ & $\begin{array}{c}\text { Yield Ratio (Cooked } \\
\text { Weight / Raw weight) }\end{array}$ \\
\hline Jam & $200.0 \mathrm{~g}$ & $150 \mathrm{~g}$ & 1.33 \\
\hline Preserve & $15.0 \mathrm{~g}$ & $100 \mathrm{~g}$ & 1.50 \\
\hline Spicy Pickle & $147.5 \mathrm{~g}$ & $110 \mathrm{~g}$ & 1.34 \\
\hline Sweet pickle & $202.5 \mathrm{~g}$ & $175 \mathrm{~g}$ & 1.15 \\
\hline Dry chutney powder & $172.5 \mathrm{~g}$ & $100 \mathrm{~g}$ & 1.72 \\
\hline Wet chutney powder & $170.5 \mathrm{~g}$ & $150 \mathrm{~g}$ & 1.13 \\
\hline Garcinia - watermelon drink & $350.0 \mathrm{ml}$ & $350 \mathrm{ml}$ & 1.00 \\
\hline Garcinia - orange squash & $400.0 \mathrm{ml}$ & $380 \mathrm{ml}$ & 1.05 \\
\hline Garcinia - pineapple Squash & $400.0 \mathrm{ml}$ & $390 \mathrm{ml}$ & 1.02 \\
\hline Garcinia - lime - ginger syrup & $452.0 \mathrm{ml}$ & $450 \mathrm{ml}$ & \\
\hline
\end{tabular}

Table 4 indicates the yield ratios of different products along with its raw and cooked weights. The Table revealed that dry chutney powder had the highest yield ratio of about 1.725 whereas Garcinia watermelon drink got the lowest yield ratio of 1 . It was found that there was no significant difference between the yield ratios of the developed products. All the products obtained yield ratios within a range of about 1 to 1.7. 


\subsubsection{Evaluation of preparation losses}

Loss of weight during cooking was calculated from the weight of the purchased raw materials and weight of the edible portion.

Table 5 Preparation loss of the developed products

\begin{tabular}{|l|c|}
\hline \multicolumn{1}{|c|}{ Product name } & Preparation loss \\
\hline Jam & 0.25 \\
\hline Preserve & 0.33 \\
\hline Spicy pickle & 0.25 \\
\hline Sweet pickle & 0.13 \\
\hline Dry chutney powder & 0.42 \\
\hline Wet chutney powder & 0.12 \\
\hline Garcinia - watermelon drink & 0.00 \\
\hline Garcinia - orange squash & 0.05 \\
\hline Garcinia - pineapple squash & 0.02 \\
\hline Garcinia - lime - ginger syrup & 0.04 \\
\hline
\end{tabular}

Table 5 shows the loss of weight during the preparation of the products. Among the developed products preparation loss was found to be higher for Garcinia dry chutney powder $(0.13 \mathrm{~g})$. The reason behind the loss was that all the ingredients were first roasted and then powdered to get a fine mixture, which resulted in increased weight loss of the dry chutney powder during preparation. The preparation loss of all the other products was negligible when compared to Garcinia dry chutney powder.

The least preparation loss was seen for wet chutney $(0.12)$, since all the ingredients are grounded to get a paste without cooking and thus cooking losses were reduced. Garcinia water melon drink showed no preparation loss, since all the fruit pulps were utilized for the preparation of the drink.

\subsubsection{Cost analysis}

Costs of the developed products were calculated on the basis of the total cost of the product / weight of the edible portion.

Table 6 Cost Analysis

\begin{tabular}{|l|c|c|c|c|}
\hline \multirow{2}{*}{ Product Name } & Amount (g) & \multicolumn{3}{c|}{ Cost analysis } \\
\cline { 3 - 5 } & & Total Cost (Rs) & $\begin{array}{c}\text { Weight of the } \\
\text { edible portion } \\
\text { (g) }\end{array}$ & $\begin{array}{c}\text { Cost of products } \\
\text { (Rs / g) }\end{array}$ \\
\hline Jam & & & $150 \mathrm{~g}$ & 5.46 \\
\hline Preserve & 100 & 8.20 & $100 \mathrm{~g}$ & 7.10 \\
\hline Spicy Pickle & 100 & 7.10 & $110 \mathrm{~g}$ & 7.46 \\
\hline Sweet pickle & 100 & 8.21 & $175 \mathrm{~g}$ & 5.80 \\
\hline Dry chutney powder & 100 & 10.21 & $100 \mathrm{~g}$ & 9.00 \\
\hline Wet chutney powder & 100 & 9.00 & $150 \mathrm{~g}$ & 5.30 \\
\hline Garcinia - watermelon drink & 100 & 8.00 & $350 \mathrm{ml}$ & 4.71 \\
\hline Garcinia - orange squash & 100 & 16.50 & $380 \mathrm{ml}$ & 8.57 \\
\hline Garcinia - pineapple Squash & 100 & 32.60 & $390 \mathrm{ml}$ & 5.28 \\
\hline $\begin{array}{l}\text { Garcinia - lime - ginger } \\
\text { syrup }\end{array}$ & 100 & 20.60 & $450 \mathrm{ml}$ & 5.46 \\
\hline
\end{tabular}

Table 6 reveals the cost of the developed products per 100g of the product. For preparing $100 \mathrm{~g}$ of dry chutney powder the cost was about Rs 9.00/- which was found to be the highest preparation cost when compared to other products. Least cost was obtained for preparing Garcinia watermelon drink which was about Rs 4.71/-. High cost in the production of $100 \mathrm{~g}$ of chutney powder is contributed by the amount of coconut used in its preparation and fuel required for roasting the ingredients without using oil.

\subsubsection{Comparison between the yield ratio and cost of the products developed products}

Table 7 Comparison between yield ratio, preparation loss and cost of the developed products

\begin{tabular}{|l|c|c|c|}
\hline \multicolumn{1}{|c|}{ Product Name } & $\begin{array}{c}\text { Yield Ratio } \\
(\mathbf{g})\end{array}$ & $\begin{array}{c}\text { Preparation loss } \\
(\mathbf{g})\end{array}$ & $\begin{array}{c}\text { Cost } \\
(\mathbf{R s})\end{array}$ \\
\hline Jam & 1.33 & 0.25 & 5.46 \\
\hline Preserve & 1.50 & 0.33 & 7.10 \\
\hline Spicy Pickle & 1.34 & 0.25 & 7.46 \\
\hline Sweet pickle & 1.15 & 0.13 & 5.80 \\
\hline Dry chutney powder & 1.72 & 0.42 & 9.00 \\
\hline Wet chutney powder & 1.13 & 0.12 & 5.30 \\
\hline Garcinia - watermelon drink & 1.00 & 0.00 & 4.71 \\
\hline Garcinia - orange squash & 1.05 & 0.05 & 8.57 \\
\hline Garcinia - pineapple squash & 1.02 & 0.02 & 5.28 \\
\hline Garcinia- lime - ginger syrup & 1.04 & 0.04 & \\
\hline
\end{tabular}


Table 7 showed the comparison between the yield ratio and cost of the developed products. This shows that the products with lower yield ratio had lower cost of preparation. As per table 7 Garcinia watermelon drink with the lowest yield ratio of 1.00 and zero preparation loss was prepared at a cost of about Rs $4.71 / 100 \mathrm{~g}$ which was found to be the product with the least cost of preparation. While dry chutney powder with highest yield ratio (1.72) and preparation loss (0.42) was having at the highest cost of preparation of about Rs 9/100g. As per the results of the comparison based on the study, the cost of a product prepared using Garcinia, is directly proportional to yield ratio as well as to the preparation loss of the product.

\section{Conclusions}

Based on the findings of the study, it can be concluded that the indigenous nutraceutical fruit Garcinia cambogia, which is a seasonal fruit, can be utilized fully to produce value added products and thereby making it available throughout the season. All the developed products were superior in nutritive value, shelf stability and had good economic qualities as well.

\section{References}

[1] R. Rao, Boosting fruits and vegetables, Yojana, 12(1), 1995,88

[2] V. Sethi,Prospects and Constraints for expert of indigenous fruit and vegetable products,Indian Food Packer, 47(3), $2000,37-41$.

[3] S. K. Roy, and R. K. Pal,Use of plastics in post harvest technology of fruits and vegetables, A review of IFP, Indian Food Packer,27(4),1993,42.

[4] S. N. Manay, and M. Shadaksharaswamy, Foods - Facts and Principles,(New Delhi: New Age International, 2006)77, 103.

[5] M. J. Whitaker,The Whitaker Wellness Weigh Lose Programmes,( US: Source Books,2006)104.

[6] Indian Council of Medical Research, Nutrient requirements and recommended dietary allowances for Indians, (Hyderabad: National Institute of Nutrition, 2011) 12.

[7] H. Hui, M. L. Nollet, B. K. Sipson, and P. Gopinadhan, Food chemistry and food processing, ( USA: Blackwell publishers,2006) 688- 692.

[8] R. D. Srivastava, and S. Kumar,Fruits and Vegetable Presevation,(Lucknow: International Book Distributing Co., 1994$), 140,273$.

[9] B. SriLakshmi, Food Science,(New Delhi: New Age International, 2006) 78. 